\title{
Intake of specific fatty acids and fat alters growth, health, and titers following vaccination in dairy calves
}

\author{
K. M. Esselburn, ${ }^{*}$ K. M. O’Diam, ${ }^{*}$ T. M. Hill, $\dagger^{1}$ H. G. Bateman II, J. M. Aldrich, $†$ R. L. Schlotterbeck, ${ }^{*}$ \\ and K. M. Daniels* \\ ${ }^{*}$ Department of Animal Sciences, The Ohio State University, Ohio Agricultural Research and Development Center, Wooster 44691 \\ †Nurture Research Center, Provimi North America, Brookville, OH 45309
}

\begin{abstract}
Typical fatty acid profiles of milk and milk replacer (MR) differ. Calf MR in the United States are made from animal fat, which are low in short- and mediumchain fatty acids and linolenic acid. Two 56-d trials compared a control MR containing $27 \%$ crude protein and formulated with 3 fat and fatty acid compositions. The $3 \mathrm{MR}$ treatments were (1) only animal fat totaling $17 \%$ fat $(\mathrm{CON}),(2)$ animal fat supplemented with butyrate, medium-chain fatty acids, and linolenic acid using a commercial product (1.25\% NeoTec4 MR; Provimi North America, Brookville, OH) totaling 17\% fat (fatty acid-supplemented; FA-S), and (3) milk fat totaling $33 \%$ fat (MF). The MR were fed at $660 \mathrm{~g}$ of dry matter from d 0 to 42 and weaned. Starter (20\% crude protein) and water were fed ad libitum for $56 \mathrm{~d}$. Trial 1 utilized Holstein calves (24 female, 24 male) during summer months and trial 2 utilized Holstein calves (48 male) during fall months. Calves $(41 \pm 1 \mathrm{~kg}$ of initial body weight; 2 to $3 \mathrm{~d}$ of age) were sourced from a single farm and housed in a naturally ventilated nursery without added heat. Calves were in individual pens with straw bedding. Calf was the experimental unit. Data for each trial were analyzed as a completely randomized design with a 3 (MR treatment) $\times 2$ (sex) factorial arrangement of treatments in trial 1 with repeated measures and as a completely randomized design with $3 \mathrm{MR}$ treatments in trial 2 with repeated measures. Preplanned contrast statements of treatments CON versus FA-S and CON versus MF were used to separate means. We found no interactions of MR treatment by sex. Calf average daily gain, hip width change, and feed efficiency differed $(\mathrm{CON}<\mathrm{FA}-\mathrm{S}$; CON $<\mathrm{MF})$. Days with abnormal fecal scores differed (CON $>$ FA-S). Titers to bovine respiratory parainfluenza- 3 and bovine virus diarrhea type 1 (vaccinations to these pathogens were on $\mathrm{d} 7$ and 28) in serum samples taken on d 49
\end{abstract}

Received January 22, 2013.

Accepted May 25, 2013.

${ }^{1}$ Corresponding author: mhill@akey.com and 56 differed (CON < FA-S). Average and daily maximum skin tail temperatures based on automated measurements taken every $10 \mathrm{~min}$ differed $(\mathrm{CON}>$ FA-S; CON < MF). Concentrations of urea nitrogen and glucose in serum samples taken on d 7, 21, and 28 differed (CON > FA-S; CON > MF). Calves fed FA-S and MF had improved growth and feed efficiency compared with calves fed CON, whereas calves fed FA-S also had improved measurements related to health and immunity.

Key words: fatty acid, health, calf, milk replacer

\section{INTRODUCTION}

Milk replacers for dairy herd replacement calves in the United States are typically formulated with animal fat as the main fat source; therefore they are relatively low in butyric (C4:0), medium-chain FA, and linolenic acids (C18:3). Additionally, calf starters and growers are relatively low in these FA. In recent research where these FA were supplemented to calves, ADG, hip width growth, feed efficiency, and days with abnormally loose feces were reduced (Hill et al., 2007a,b,c, 2009a, 2011a,c; Fokkink et al., 2009). Additionally, calves supplemented with butyric, medium chain, and linolenic acids were shown to have improved markers of both short- and long-term immunity (Hill et al., 2011a,c).

Butyrate, linolenic acid, and the other longer chain FA found in fish oil have numerous metabolically active properties. Each has a role in immune function (Saemann et al., 2000; Nancey et al., 2002; Zhao et al., 2007) as well as growth (Klein, 2002; Hill et al., 2007a; Guilloteau et al., 2009). Medium-chain FA have antimicrobial and antiviral properties (Hristov et al., 2004) and enhance responses to linolenic acid (Hill et al., 2007a). Feeding fish oil, a source of other biologically active FA, has not been reported to improve calf health or performance (Ballou and DePeters, 2008; Hill et al., 2009a).

To date, most of the work with FA in calves has been conducted in male calves with marginal concentrations of serum protein $(<5.5 \mathrm{mg} / \mathrm{dL})$, an indication of pas- 
sive transfer of colostral immunity. Additionally, milk fat may have an optimum profile of FA. To the authors' knowledge, liquid diets (milk or MR) with equal CP and containing either animal fat or milk fat have not been compared. Two trials were conducted with $2 \mathrm{MR}$ with and without added FA and a third treatment based on dried whole milk. Our hypothesis was that calves fed diets based on animal fat and supplemented with butyric acid, medium-chain FA, and linolenic acid would have superior calf growth, health, and markers of immunity compared with diets not supplemented with these FA.

\section{MATERIALS AND METHODS}

Calves were cared for by acceptable practices as described in the Guide for the Care and Use of Agricultural Animals in Research and Teaching (FASS, 2010). Trials 1 and 2 compared a control MR containing $27 \% \mathrm{CP}$ and formulated with 3 fat and FA compositions. The $3 \mathrm{MR}$ treatments in each trial were (1) only animal fat (CON), (2) animal fat supplemented with butyrate, medium-chain FA, and linolenic acid (FA-supplemented, FA-S) using a commercial product $(1.25 \%$ NeoTec4 MR, Provimi North America, Brookville, OH), and (3) milk fat (MF). Milk replacers CON and FA-S were manufactured from whey, whey protein concentrate, and animal fat encapsulated with whey protein, as is typical in the US feed industry; they were $17 \%$ fat. Milk replacer MF was dry, whole milk selected to be $27 \% \mathrm{CP}$ and $33 \%$ fat. Dry milk was used instead of liquid milk to provide a consistent product each day that was equal in $\mathrm{CP}$ to the $\mathrm{CON}$ and FA-S treatments. The higher fat content of MF was planned, as it contains a normal amount of fat (DM basis) present in whole milk from Holstein cows. However, milk is high in butyrate, medium-chain FA, and linolenic acid compared with animal fat. Whole milk contains a large amount of casein, whereas most MR are whey-based and contain little casein. Providing proteins as either casein or whey is not typically known to alter ADG, health, or digestion in herd-replacement dairy calves (Terosky et al., 1997; Lammers et al., 1998). All MR powders were blended with a common trace mineral and vitamin premix before bagging. All calves were fed a common textured calf starter $(20 \% \mathrm{CP}$ on a DM basis; $37 \%$ whole corn, $35 \%$ supplement pellet, $25 \%$ whole oats, $3 \%$ molasses; supplement pellet contained $66 \%$ soybean meal, $22 \%$ wheat middlings, $9 \%$ minerals and vitamins, $3 \%$ molasses) and fresh water ad libitum. Holstein calves ( 2 to $3 \mathrm{~d}$ of age; 24 male and 24 female in trial 1; 48 male in trial 2) from a single dairy farm were transported $3.5 \mathrm{~h}$ to the Nurture Research Center in southwest Ohio and received at $\sim 1100 \mathrm{~h}$. Calves were fed CON for the first 2 feedings, and thereafter, they were randomly assigned to treatments and locations within the nursery. At $1100 \mathrm{~h}$ on the day after arrival, calves were weighed (initial BW), blood was sampled from the jugular vein, serum was harvested, and serum protein concentration was immediately measured using an optical refractometer (Atago U.S.A. Inc., Bellevue, WA). At this time, calves were blocked by sex (trial 1 only) and randomly assigned to treatments. The MR were diluted at $150 \mathrm{~g} / \mathrm{L}$ total volume with warm water and fed at $660 \mathrm{~g}$ of $\mathrm{DM}$ divided into equal a.m. and p.m. meals. On the last $3 \mathrm{~d}$ preweaning, calves were fed only their a.m. feeding and were completely weaned after $42 \mathrm{~d}$ on trial. The trials continued for an additional $14 \mathrm{~d}$ postweaning to include $56 \mathrm{~d}$ overall.

Every second bag $(22.7 \mathrm{~kg})$ of $\mathrm{MR}$ and starter feed was sampled and composited. Composites of feeds were analyzed (AOAC International, 2000) for DM (oven method 930.15), CP (Kjeldahl method 988.05), fat (alkaline treatment with Röse-Gottlieb method 932.06 for MR; diethyl ether extraction method 2003.05 for starters and hay), and FA (by GC; method 963.22). Additionally, the starter was analyzed for NDF with ash by the procedure of Van Soest et al. (1991) without sodium sulfite or $\alpha$-amylase, and ADF with ash (Robertson and Van Soest, 1981). Results are given in Table 1.

Calves were weighed every $7 \mathrm{~d}$ until the end of the trial (d 56). Dry feed offered and feed refusals were weighed daily. Fecal scores were assigned daily based on a 1 to 5 system ( 1 being normal, thick in consistency; 2 being normal, but less thick; 3 being abnormally thin but not watery; 4 being watery; 5 being watery with abnormal coloring; modified from Kertz and ChesterJones, 2004). Hip widths were measured with a caliper, and body condition of calves was measured at $\mathrm{d} 0$ and every $14 \mathrm{~d}$ thereafter. A 1 to 5 system with 0.25 -unit increments was used for BCS $(1=$ emaciated, $5=$ obese; Wildman et al., 1982). Scores were based on changes around the vertical and transverse processes of the spine as palpated by one experienced technician and ranged from 1.5 to 3.5. Technicians were blind to the treatments. The 56-d trial 1 was conducted during the months of August and September. The average ambient temperature inside the barn during the trial was $20^{\circ} \mathrm{C}$ and ranged from 5 to $38^{\circ} \mathrm{C}$ based on hourly measurements. The 56-d trial 2 was conducted during the months of October and November. The average ambient temperature inside the barn during the trial was $7^{\circ} \mathrm{C}$ and ranged from -9 to $22^{\circ} \mathrm{C}$ based on hourly measurements.

Calves were housed in $1.2 \times 2.4 \mathrm{~m}$ individual pens within a curtain sidewall barn with no added heat. The pens were bedded with long straw. Calves received an 
Table 1. Nutrients concentrations (DM basis) of feeds

\begin{tabular}{|c|c|c|c|c|}
\hline \multirow[b]{2}{*}{ Item } & \multicolumn{3}{|c|}{ Milk replacer treatment ${ }^{1}$} & \multirow[b]{2}{*}{ Starter } \\
\hline & $\mathrm{CON}$ & FA-S & $\mathrm{MF}$ & \\
\hline \multicolumn{5}{|l|}{ Analyzed, \% } \\
\hline $\mathrm{DM}$ & 96.7 & 96.5 & 96.6 & 87.5 \\
\hline $\mathrm{CP}$ & 27.5 & 27.2 & 27.8 & 20.9 \\
\hline Fat & 17.9 & 17.6 & 33.4 & 5.1 \\
\hline $\mathrm{ADF}$ & $\mathrm{ND}^{2}$ & ND & ND & 6.2 \\
\hline $\mathrm{NDF}$ & ND & ND & ND & 12.4 \\
\hline ME, Mcal/kg & 4.8 & 4.8 & 5.6 & 3.3 \\
\hline \multicolumn{5}{|l|}{$\mathrm{FA}, \%$} \\
\hline $\mathrm{C} 4$ & 0.04 & 0.46 & 0.42 & 0.02 \\
\hline C6 & $<0.01$ & $<0.01$ & 0.62 & $<0.01$ \\
\hline $\mathrm{C} 8$ & $<0.01$ & 0.01 & 2.90 & $<0.01$ \\
\hline C10 & $<0.01$ & 0.07 & 0.17 & $<0.01$ \\
\hline $\mathrm{C} 12$ & 0.03 & 0.51 & 0.17 & 0.02 \\
\hline C14 & 0.02 & 0.19 & 0.73 & 0.01 \\
\hline $\mathrm{C} 16: 0$ & 4.08 & 3.76 & 8.74 & 0.31 \\
\hline $\mathrm{C} 16: 1$ & 0.48 & 0.46 & 0.49 & 0.11 \\
\hline C18:0 & 2.22 & 1.97 & 3.93 & 0.16 \\
\hline C18:1 & 7.89 & 7.29 & 9.66 & 1.06 \\
\hline C18:2 & 1.54 & 1.42 & 3.86 & 1.71 \\
\hline $\mathrm{C} 18: 3$ & 0.06 & 0.18 & 0.34 & 0.07 \\
\hline Ratio $\mathrm{C} 18: 2$ to $\mathrm{C} 18: 3$ & 25.2 & 7.9 & 11.5 & 25.2 \\
\hline
\end{tabular}

${ }^{1} \mathrm{CON}=17 \%$ fat from animal fat; FA-S $=17 \%$ fat from animal fat supplemented with added FA from NeoTec4 milk replacer (Provimi North America, Brookville, $\mathrm{OH}$ ); $\mathrm{MF}=33 \%$ fat from milk fat.

${ }^{2} \mathrm{ND}=$ not determined.

intranasal tissue sensitive respiratory disease vaccine (TSV-2, Pfizer, Exton, PA) and subcutaneous injections of vitamins A, D, E (Vital E-A + D, Schering-Plough Animal Health, Union, NJ) and Se (MU-SE, ScheringPlough Animal Health) upon arrival. Calves received an injection of Bovashield Gold 5 (Pfizer) at $\mathrm{d} 7$ and again at $\mathrm{d} 28$, a vaccine used with the measurement of bovine viral diarrhea (BVD) and parainfluenza-3 (PI3) titers described later. Male calves were castrated and dehorned at $39 \mathrm{~d}$ of age. All medical treatments and protocols were under supervision of a veterinarian and were based on scouring (fecal scores $>2$ ), lethargy, elevated rectal temperatures, and rapid breathing.

A Thermocron temperature sensor (Maxim Integrated Products Inc., Sunnyvale, CA) was attached to the underside of the tail immediately proximal to the observable vein using expandable tape (Vetrap, 3M, St. Paul, MN) on 8 calves per treatment (all heifers in trial 1). Temperature readings were captured automatically every $10 \mathrm{~min}$. Thermocron attachment periods were d 1 to 26 and d 28 to 56 ; the sensors were removed for a day to download the data. Temperatures from the Thermocrons were used as a proxy of body temperature (van Marken Lichtenbelt et al., 2006; Smith et al., 2010; Bateman et al., 2012a).

In trial 1, blood samples without EDTA were collected from the same 4 female calves per treatment (that were randomly selected) on d $0,7,21$, and 28 . Samples were allowed to clot and serum was separated by centrifugation at $1,000 \times g$ for $10 \mathrm{~min}$ at room temperature (approximately $22^{\circ} \mathrm{C}$ ), and immediately analyzed for albumin, alkaline phosphatase, amylase, creatinine, glucose, total protein, urea-N, and globular protein (estimated as total protein minus albumin), as described in Hill et al. (2007a). Additionally, blood samples without EDTA were collected from all calves on d 0,49, and 56. Samples were allowed to clot, serum was separated by centrifugation (at $1,000 \times g$ for 10 min at room temperature) and frozen $\left(-20^{\circ} \mathrm{C}\right)$ until later analysis for titers to bovine respiratory PI3 and BVD by The Ohio State University Diagnostic Laboratory (Reynoldsburg).

Growth data were analyzed using the MIXED procedure in SAS (version 8, SAS Institute Inc., Cary, NC) as a completely randomized design with a 3 (MR treatment $) \times 2$ (sex) factorial arrangement of treatments. The repeated-measures mixed model in trial 1 was as follows:

$$
\begin{gathered}
\mathrm{Y}_{\mathrm{ijkl}}=\mu+\mathrm{T}_{\mathrm{i}}+\mathrm{S}_{\mathrm{j}}+\mathrm{TS}_{\mathrm{ij}}+\mathrm{W}_{\mathrm{k}}+\mathrm{TW}_{\mathrm{ik}} \\
+\mathrm{SW}_{\mathrm{jk}}+\mathrm{TSW}_{\mathrm{ijk}}+\varepsilon_{\mathrm{ijk} \mathrm{k}},
\end{gathered}
$$

where $Y_{i j k l}$ is observed response; $T_{i}$ is fixed effect of treatment $\mathrm{i} ; \mathrm{S}_{\mathrm{j}}$ is fixed effect of sex $\mathrm{j}$; $\mathrm{TS}_{\mathrm{ij}}$ is the interaction of treatment $\mathrm{i}$ and sex $\mathrm{j} ; \mathrm{W}_{\mathrm{k}}$ is the repeated effect of week $\mathrm{k}$ that was modeled as an auto-regressive type 1 covariance matrix within experimental unit; $\mathrm{TW}_{\mathrm{ik}}$, 
$\mathrm{SW}_{\mathrm{jk}}$, and $\mathrm{TSW}_{\mathrm{ijk}}$ are the interactions of treatment $\mathrm{i}$, sex $\mathrm{j}$ and week k; and $\varepsilon_{\mathrm{ijkl}}$ is error using the KenwardRogers procedures for determining the degrees of freedom. In trial 1, d 0 titers and blood constituents were used as a covariate within the model. In trial 2 , the model was the same completely randomized design with $\mathrm{Sj}$ removed. Treatment means were separated using preplanned contrast statements (CON vs. FA-S; CON vs. MF). All data are reported as least squares means. The experimental unit was calf. Statistical differences are discussed at $P<0.05$, and trends are mentioned when $P<0.10$.

\section{RESULTS}

\section{Trial 1}

Analyses of the diets are shown in Table 1. The concentration of butyrate was about 10 times greater in FA-S and MF than in CON. The sum of the mediumchain FA capric acid (C10:0), lauric acid (C12:0), and myristic acid (C14:0) was 14 to 20 times greater in FA-S and $\mathrm{MF}$ than in CON. The concentration of linolenic acid was 3 to 5 times greater in FA-S and MF than in $\mathrm{CON}$. The linoleic acid concentrations were similar in $\mathrm{CON}$ and FA-S, but about 2.5 times greater in MF than CON and FA-S.

Initial calf measurements did not differ among the 3 MR treatments (Table 2), but male calves were initially heavier and had wider hips and lower serum protein concentrations than female calves. We observed no MR treatment $\times$ sex interactions. We found time effects for ADG, hip width change, and starter intake: all increased with age. Feed efficiency, fecal scores, days with abnormal fecal scores, and medical treatments decreased with age.

Milk replacer offered was completely consumed (Table 3). Intakes of starter and ME (Mcal and Mcal/ $\mathrm{kg}$ of BW) were not different among treatments. Total FA intake for the entire 56-d trial differed by treatment and was relative to MR concentrations of included FA. Male calves consumed more starter than female calves. Energy intake (Mcal of ME and Mcal of ME per $\mathrm{kg}$ of BW) was not different by sex, except that energy intake as Mcal of ME intake postweaning was greater for male compared with female calves. Total FA intake for the entire 56-d trial did not differ by sex.

Preweaning and overall ADG were greater for calves fed FA-S and MF than for calves fed CON (Table 4). Postweaning ADG tended to be greater for calves fed FA-S compared with CON. Feed efficiency was greater for calves fed FA-S and MF than for those fed CON. Medical days (preweaning and overall) were less for calves fed FA-S compared with those fed CON. Medical days postweaning were greater for calves fed MF compared with CON. Abnormal fecal score days were less preweaning and tended to be less overall for calves fed FA-S than for those fed CON. Overall hip width change was greater for calves fed FA-S and MF compared with CON. Overall BCS change was greater for calves fed MF than for those fed CON. Mean and daily maximum tail skin temperatures were lower for calves fed FA-S compared with CON and higher for calves fed MF compared with CON.

Postweaning and overall ADG were greater for male than for female calves. Postweaning hip width change was greater for male than female calves. Postweaning medical days were greater for male than for female calves. Feed efficiency did not differ by sex.

Serum total protein concentration tended to be greater in calves fed FA-S compared with CON (Table 5). Serum albumin, urea N, and glucose concentrations were greater in calves fed FA-S and MF than in those fed CON. Serum amylase concentration was greater for calves fed FA-S compared with CON. Serum creatinine concentrations were greater for calves fed MF than CON. Serum concentrations of alkaline phosphatase and globular protein did not differ. Serum titers to BVD and PI3 determined on d 0,49 , and 56 (vac-

Table 2. Calf numbers, initial serum protein, initial and final BW, initial hip widths, and initial BCS when calves were fed 3 milk replacers with different fat and FA compositions in trial 1

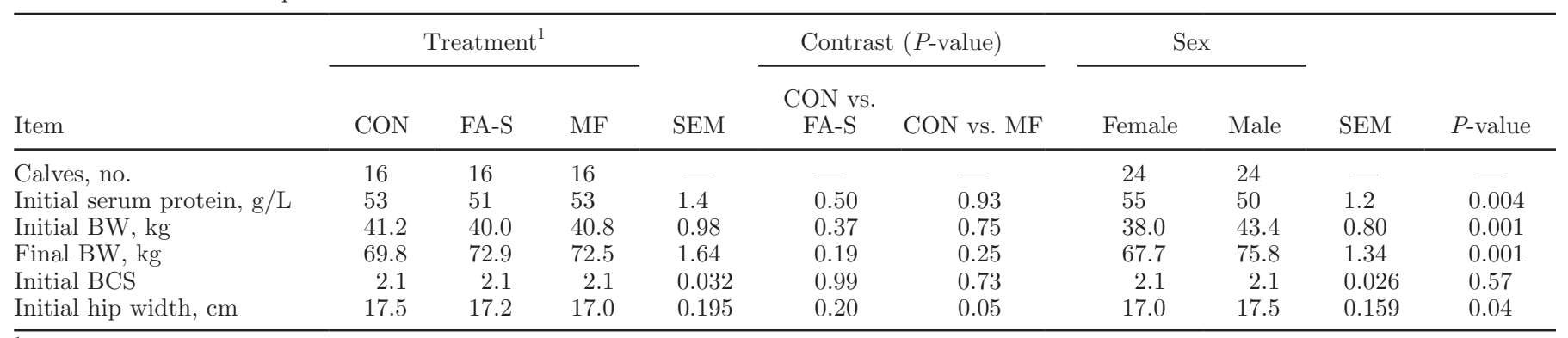

${ }^{1} \mathrm{CON}=17 \%$ fat from animal fat; FA-S $=17 \%$ fat from animal fat supplemented with added FA from NeoTec4 milk replacer (Provimi North America, Brookville, $\mathrm{OH}) ; \mathrm{MF}=33 \%$ fat from milk fat. 
Table 3. Nutrients intakes of calves fed 3 milk replacers with different fat and FA compositions in trial 1



${ }^{1} \mathrm{CON}=17 \%$ fat from animal fat; FA-S $=17 \%$ fat from animal fat supplemented with added FA from NeoTec4 milk replacer (Provimi North America, Brookville, $\mathrm{OH}) ; \mathrm{MF}=33 \%$ fat from milk fat.

cinated for BVD and PI3 on $\mathrm{d} 7$ and 28) were greater in calves fed FA-S than in those fed CON.

\section{Trial 2}

Results in trial 2 were similar to results in trial 1 except that ADG and other growth measures were numerically greater than in trial 1 . We have previously noted this in this research unit (Bateman et al., 2012b) and hypothesize that the deep bedding used may allow the young calf to modify its environment to be more accommodating during periods of perceived cold stress but that the calf cannot modify its environment to overcome the effects of apparent heat stress. Initial calf measurements did not differ among the $3 \mathrm{MR}$ treatments (Table 6). We observed time effects for ADG, hip width change, and starter intake: all increased with age. Feed efficiency, fecal scores, days with abnormal fecal scores, and medical treatments decreased with age.

Milk replacer offered was completely consumed (Table 7). Intake of starter and ME (Mcal and Mcal/kg of BW) were not different among treatments, with the exception that postweaning starter intake was greater in calves fed FA-S compared with those fed CON. Total FA intake for the entire 56-d trial differed by treatment and was relative to MR concentrations.

Preweaning and overall ADG were greater for calves fed FA-S and MF than for those fed CON (Table 8). Postweaning ADG was greater for calves fed FA-S compared with those fed CON. Preweaning and overall feed efficiency were greater for calves fed FA-S and MF compared with CON. Medical days (preweaning and overall) were less for calves fed FA-S than CON. Abnormal fecal score days (preweaning and overall) were less for calves fed FA-S than CON. Postweaning and overall hip width changes were greater for calves fed FA-S than CON, whereas overall hip width change was greater for calves fed MF than for those fed CON. Changes in BCS were not different. Mean and daily maximum tail skin temperatures were lower for calves fed FA-S and higher for calves fed MF compared with CON.

\section{DISCUSSION}

Responses in trials 1 and 2 to FA-S were consistent with previous increases in ADG and hip width change, reduced abnormal fecal scores and medical treatments, and increased titers to bovine BVD and PI3 (Hill et al., 2007a,b,c, 2009a, 2011a,c; Fokkink et al., 2009). Butyric acid, a component of FA-S, has been reported to increase digestive enzyme secretions, including amylase, as well as ADG in calves (Kato et al., 1989; Guilloteau et al., 2009; Górka et al., 2011). Serum concentrations of amylase were greater in calves fed FA-S than in calves fed CON or MF. Butyric acid has also been shown to contribute to rumen development (Sander et al., 1959). Days with abnormal fecal scores were reduced during the preweaning period for calves fed FA-S compared with CON. Butyric acid has been 
Table 4. Performance of calves fed 3 milk replacers with different fat and FA compositions in trial 1

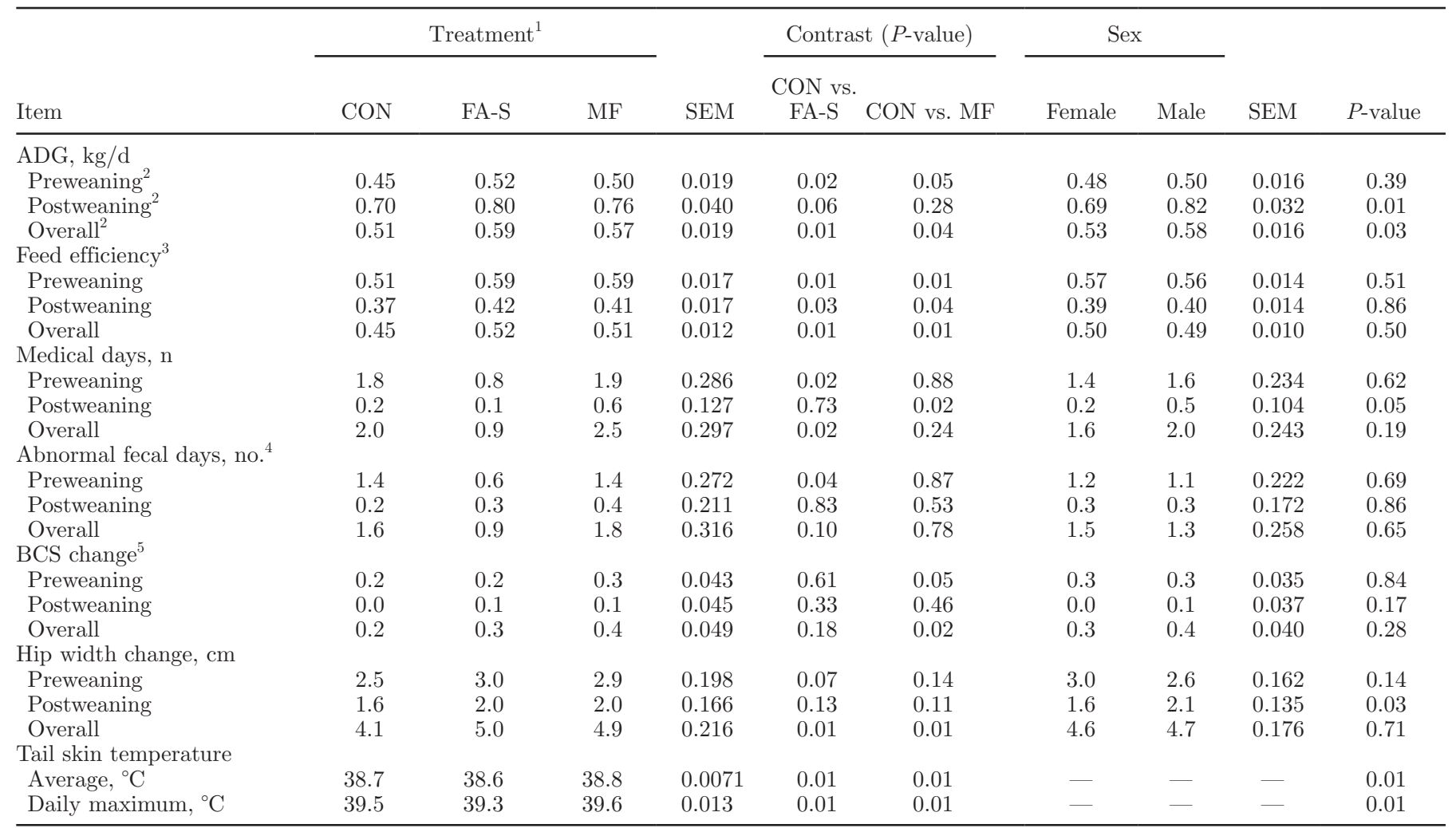

${ }^{1} \mathrm{CON}=17 \%$ fat from animal fat; FA-S $=17 \%$ fat from animal fat supplemented with added FA from NeoTec4 milk replacer (Provimi North America, Brookville, $\mathrm{OH}) ; \mathrm{MF}=33 \%$ fat from milk fat.

${ }^{2}$ Preweaning was 0 to $42 \mathrm{~d}$, postweaning was 43 to $56 \mathrm{~d}$, and overall was 0 to $56 \mathrm{~d}$.

${ }^{3}$ Gain divided by milk replacer plus starter intake.

${ }^{4}$ Where 1 = normal, thick in consistency; $2=$ normal, but less thick; $3=$ abnormally thin but not watery; $4=$ watery; $5=$ watery with abnormal coloring. Average fecal scores ranged from 2.0 to 2.1 and were not different $(P>0.50)$.

${ }^{5}$ Scale of 1 to 5 based on Wildman et al. (1982).

Table 5. Serum constituents ${ }^{1}$ and titers ${ }^{2}$ determined in calves fed 3 milk replacers with different fat and FA compositions in trial 1

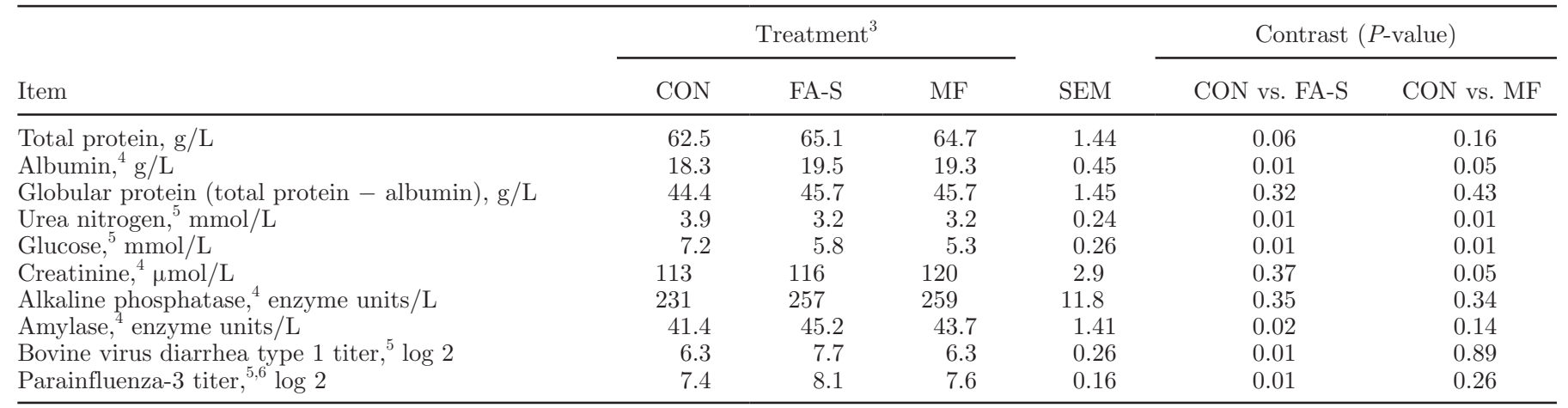

${ }^{1}$ Four female calves per treatment sampled on d 0, 7, 21, and 28 at 90 min after the a.m. milk replacer feeding.

${ }^{2}$ Sixteen calves (all) per treatment sampled on d 0, 49, and 56 at 90 min after the a.m. milk replacer feeding. We found no effect of sex or treatment $\times$ sex.

${ }^{3} \mathrm{CON}=17 \%$ fat from animal fat; FA-S $=17 \%$ fat from animal fat supplemented with added FA from NeoTec4 milk replacer (Provimi North America, Brookville, $\mathrm{OH}) ; \mathrm{MF}=33 \%$ fat from milk fat.

${ }^{4}$ Increased with age $(P<0.05)$.

${ }^{5}$ Decreased with age $(P<0.05)$.

${ }^{6}$ Greater in female than in male calves $(P<0.05)$. 
Table 6. Calf numbers, initial serum protein, initial and final BW, initial hip widths, and initial BCS when calves were fed 3 milk replacers with different fat and FA compositions in trial 2

\begin{tabular}{|c|c|c|c|c|c|c|}
\hline \multirow[b]{2}{*}{ Item } & \multicolumn{3}{|c|}{ Treatment $^{1}$} & \multirow[b]{2}{*}{ SEM } & \multicolumn{2}{|c|}{ Contrast ( $P$-value) } \\
\hline & $\mathrm{CON}$ & FA-S & MF & & CON vs. FA-S & $\mathrm{CON}$ vs. $\mathrm{MF}$ \\
\hline Initial BW, kg & 43.6 & 42.3 & 44.0 & 1.28 & 0.48 & 0.79 \\
\hline Final BW, kg & 78.4 & 82.6 & 83.2 & 1.71 & 0.09 & 0.06 \\
\hline Initial BCS & 2.2 & 2.2 & 2.2 & 0.03 & 0.73 & 0.73 \\
\hline
\end{tabular}

${ }^{1} \mathrm{CON}=17 \%$ fat from animal fat; FA-S $=17 \%$ fat from animal fat supplemented with added FA from NeoTec4 milk replacer (Provimi North America, Brookville, $\mathrm{OH}) ; \mathrm{MF}=33 \%$ fat from milk fat.

reported to be involved with intestinal barrier function (Peng et al., 2009), and butyric and linolenic acids are reported to have antiinflammatory (Saemann et al., 2000, Zhao et al., 2007; Farran et al., 2008), immunomodulatory (Caroprese et al., 2009), and other (Hu et al., 1999, Merchant et al., 2005) human health benefits. Mean and daily maximum tail skin temperatures were lower for calves fed FA-S than for those fed CON, possibly because of the antiinflammatory effects of butyric and linolenic acids (Saemann et al., 2000; Zhao et al., 2007; Farran et al., 2008). This could be particularly beneficial to calves during periods of hot weather or heat stress, as was the case in trial 1, when the ambient temperature was frequently above the upper critical temperature $\left(25^{\circ} \mathrm{C}\right)$ of the thermoneutral zone of young calves (NRC, 2001). Similarly high ambient temperatures have been associated high respiration rates and poor ADG in young dairy calves that were ameliorated when fans were used to cool the calves
(Hill et al., 2011b). Mean and daily maximum tail skin temperatures were higher for calves fed MF compared with those fed CON and may be due to the inflammatory nature of linoleic acid, the concentration of which was greater in MF compared with $\mathrm{CON}$ and in $\mathrm{CON}$ compared with FA-S (Liou et al., 2007)

Serum albumin concentrations were greater and serum total protein concentrations tended to be greater in calves fed FA-S compared with those fed CON. Serum albumin concentrations were greater in calves fed MF compared with those fed CON. Serum total protein and albumin are sometimes reported to decline in animals with disease because of increased catabolism of protein, vascular leakage with increased vascular permeability, and changes in liver synthesis of protein (Kim et al., 2003; Orhue et al., 2005; Merck Veterinary Manual, 2008). Serum urea N and glucose were lower in calves fed FA-S and MF and creatinine was higher in calves fed MF when each was compared with CON; this could

Table 7. Nutrient intakes of calves fed 3 milk replacers with different fat and FA compositions ${ }^{1}$ in trial 2

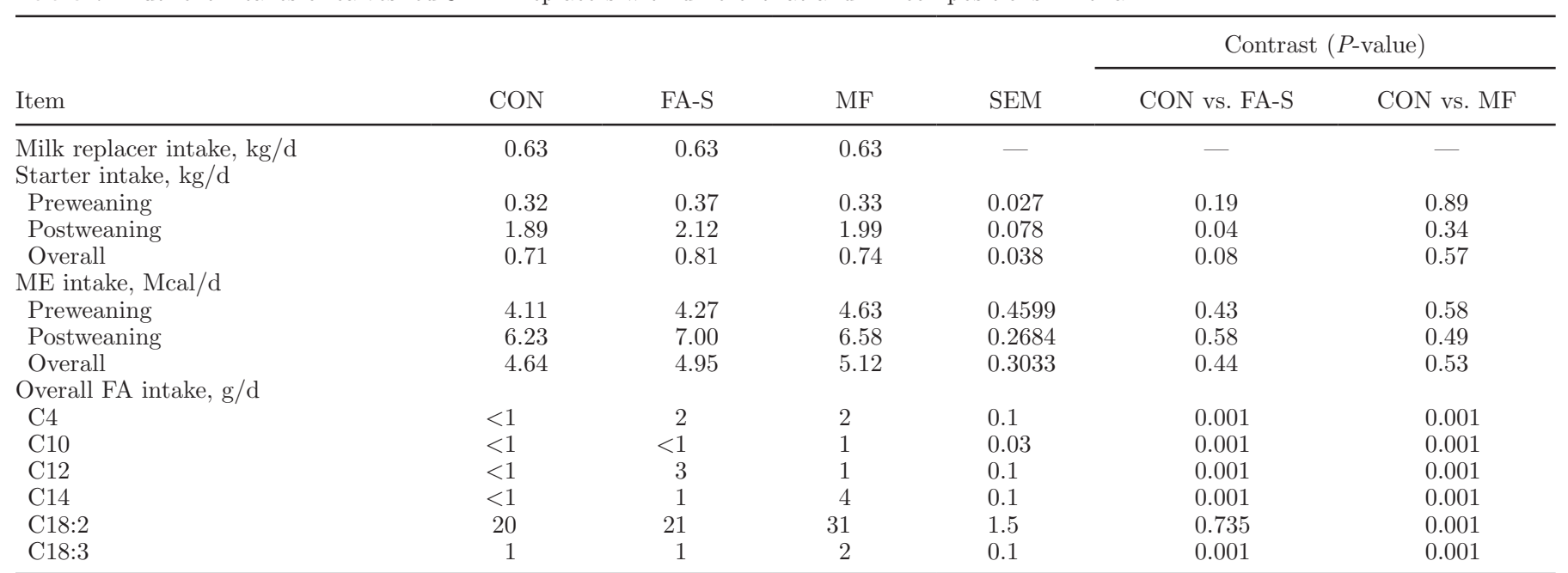

${ }^{1} \mathrm{CON}=17 \%$ fat from animal fat; FA-S $=17 \%$ fat from animal fat supplemented with added FA from NeoTec4 milk replacer (Provimi North America, Brookville, $\mathrm{OH}) ; \mathrm{MF}=33 \%$ fat from milk fat. 
Table 8. Performance of calves fed 3 milk replacers with different fat and FA compositions in trial 2



${ }^{1} \mathrm{CON}=17 \%$ fat from animal fat; FA-S $=17 \%$ fat from animal fat supplemented with added FA from NeoTec4 milk replacer (Provimi North America, Brookville, $\mathrm{OH}) ; \mathrm{MF}=33 \%$ fat from milk fat.

${ }^{2}$ Preweaning was 0 to $42 \mathrm{~d}$, postweaning was 43 to $56 \mathrm{~d}$, and overall was 0 to $56 \mathrm{~d}$.

${ }^{3}$ Gain divided by milk replacer plus starter intake.

${ }^{4}$ Where $1=$ normal, thick in consistency; $2=$ normal, but less thick; $3=$ abnormally thin but not watery; $4=$ watery; $5=$ watery with abnormal coloring. Average fecal scores ranged from 2.0 to 2.1 and were not different $(P>0.09)$.

${ }^{5}$ Scale of 1 to 5 based on Wildman et al. (1982).

indicate better $\mathrm{N}$ retention in tissue or less loss of $\mathrm{N}$ during infectious bovine rhinotracheitis or other disease challenges (Orr et al., 1988).

The higher fat and ME intake provided by MF did not result in more ADG or greater hip width change or BCS change. Increased fat and ME intake from MR has frequently resulted in no change or reduced ADG, protein accretion, and measures of structural growth (Bascom et al., 2007; van den Borne, 2007; Hill et al., 2009b,c,d). The protein to energy ratio of MF was low compared with estimates of optimum ratios in calves, whereas the protein to energy ratio of FA-S was near optimum in the trials conducted above and below the lower critical temperature of thermoneutrality (Bartlett et al., 2006; Hill et al., 2009c,d).

\section{CONCLUSIONS}

Including a specific amount of butyric, medium-chain, and linolenic acids in milk replacers low in these FA and based on animal fat improved ADG, hip width change, feed efficiency, and antibody titers against BVD and
PI3, and reduced days with abnormal fecal scores and skin tail temperature in dairy calves less than 2 mo of age (FA-S vs. CON). Similarly, feeding a dried milk of similar CP concentration (27\%) but higher fat (33\% vs. $17 \%$ ) improved ADG, hip width change, and feed efficiency, but did not increase antibody titers against BVD and PI3 and slightly increased skin tail temperature (MF vs. CON). Treatment responses were consistent in female (higher initial serum protein concentrations) and male calves (lower initial serum protein concentrations). Treatment responses were also consistent in the summer (higher ambient temperatures) and fall (lower ambient temperatures). These findings indicate that altering the FA profile of MR away from $100 \%$ edible lard (FA-S vs. CON) and changing the total amount and profile of FA fed (MF vs. CON) can positively affect calf growth and performance.

\section{REFERENCES}

AOAC International. 2000. Official Methods of Analysis. Vol. I. 17th ed. AOAC International, Arlington, VA. 
Ballou, M. A., and E. J. DePeters. 2008. Supplementing milk replacer with omega-3 fatty acids from fish oil on immunocompetence and health of Jersey calves. J. Dairy Sci. 91:3488-3500.

Bartlett, K. S., F. K. McKeith, M. J. VandeHaar, G. E. Dahl, and J. K. Drackley. 2006. Growth and body composition of dairy calves fed milk replacers containing different amounts of protein at two feeding rates. J. Anim. Sci. 84:1454-1467.

Bascom, S. A., R. E. James, M. L. McGilliard, and M. Van Amburgh. 2007. Influence of dietary fat and protein on body composition of Jersey bull calves. J. Dairy Sci. 90:5600-5609.

Bateman, H. G. II, T. M. Hill, J. M. Aldrich, A. B. Chestnut, and R. L. Schlotterbeck. 2012a. Use of tail skin temperature as a proxy for core body temperature in neonatal Holstein male calves. J. Dairy Sci. 95(Suppl. 2):717. (Abstr.)

Bateman, H. G. II, T. M. Hill, J. M. Aldrich, R. L. Schlotterbeck, and J. L. Firkins. 2012b. Meta-analysis of the effect of initial serum protein concentration and empirical prediction model for growth of neonatal Holstein calves through 8 weeks of age. J. Dairy Sci. 95:363-369.

Caroprese, M., A. Marzano, G. Entrican, S. Wattegedera, M. Albenzio, and A. Sevi. 2009. Immune response of cows fed polyunsaturated fatty acids under high ambient temperatures. J. Dairy Sci. 92:2796-2803.

Farran, T. B., C. D. Reinhardt, D. A. Blasi, J. E. Minton, T. H. Elsasser, J. J. Higgins, and J. S. Drouillard. 2008. Source of dietary lipid may modify the immune response in stressed feeder cattle. J. Anim. Sci. 86:1382-1394

FASS. 2010. Guide for the Care and Use of Agricultural Animals in Research and Teaching. 3rd ed. Federation of Animal Science Societies (FASS), Champaign, IL

Fokkink, W. B., T. M. Hill, H. G. Bateman II, J. M. Aldrich, and R. L. Schlotterbeck. 2009. Selenium yeast for dairy calf feeds. Anim. Feed Sci. Technol. 153:228-235.

Górka, P., Z. M. Kowalski, P. Pietrzak, A. Kotunia, W. Jagusiak, J. J. Holst, P. Guillotieau, and R. Zabielski. 2011. Effect of method of delivery of sodium butyrate on rumen development in newborn calves. J. Dairy Sci. 94:5578-5588.

Guilloteau, P., R. Zabielski, J. C. David, J. W. Blum, J. A. Morisset, M. Biernat, J. Woliński, D. Laubitz, and Y. Hamon. 2009. Sodiumbutyrate as a growth promoter in milk replacer formula for young calves. J. Dairy Sci. 92:1038-1049.

Hill, T. M., J. M. Aldrich, R. L. Schlotterbeck, and H. G. Bateman II. 2007a. Effects of changing the fat and fatty acid composition of milk replacers fed to neonatal calves. Prof. Anim. Sci. 23:135-143.

Hill, T. M., J. M. Aldrich, R. L. Schlotterbeck, and H. G. Bateman II. 2007b. Amino acids, fatty acids, and fat sources for calf milk replacers. Prof. Anim. Sci. 23:401-408.

Hill, T. M., J. M. Aldrich, R. L. Schlotterbeck, and H. G. Bateman II 2007c. Effects of changing the fatty acid composition of calf starters. Prof. Anim. Sci. 23:665-671.

Hill, T. M., H. G. Bateman II, J. M. Aldrich, and R. L. Schlotterbeck. 2009a. Effects of changing the essential and functional fatty acid intake of dairy calves. J. Dairy Sci. 92:670-676.

Hill, T. M., H. G. Bateman II, J. M. Aldrich, and R. L. Schlotterbeck. 2009b. Optimizing nutrient ratios in milk replacers for calves less than five weeks of age. J. Dairy Sci. 92:3281-3291.

Hill, T. M., H. G. Bateman II, J. M. Aldrich, and R. L. Schlotterbeck. 2009c. Effects of fat concentration of a high protein milk replacer on calf performance. J. Dairy Sci. 92:5147-5153.

Hill, T. M., H. G. Bateman II, J. M. Aldrich, and R. L. Schlotterbeck. 2009d. Effect of consistency of nutrient intake from milk and milk replacer on dairy calf performance. Prof. Anim. Sci. 25:85-92.

Hill, T. M., H. G. Bateman II, J. M. Aldrich, and R. L. Schlotterbeck. 2011a. Impact of various fatty acids on dairy calf performance. Prof. Anim. Sci. 27:167-175.

Hill, T. M., H. G. Bateman II, J. M. Aldrich, and R. L. Schlotterbeck. 2011b. Comparison of housing, bedding, and cooling options for calves. J. Dairy Sci. 94:2138-2146.

Hill, T. M., M. J. VandeHaar, L. M. Sordillo, D. R. Catherman, H. G. Bateman II, and R. L. Schlotterbeck. 2011c. Fatty acid in- take alters growth and immunity of milk-fed calves. J. Dairy Sci 94:3936-3948.

Hristov, A. N., M. Ivan, and T. A. McAllister. 2004. In vitro effects of individual fatty acids on protozoal numbers and on fermentation products in ruminal fluid from cattle fed a high concentrate, barley-based diet. J. Anim. Sci. 82:2693-2704.

Hu, F. B., M. J. Stampfer, J. E. Manson, E. B. Rimm, A. Wolk, G. A Colditz, C. H. Hennekens, and W. C. Willett. 1999. Dietary intake of a-linolenic acid and risk of fatal ischemic heart disease among women. Am. J. Clin. Nutr. 69:890-897.

Kato, S., N. Asakawa, H. Mineo, and J. Ushijima. 1989. Effect of short-chain fatty acids on pancreatic exocrine secretion in calves aged 2 weeks and 13 weeks. Japanese J. Vet. Sci. 51:123-127.

Kertz, A. F., and H. Chester-Jones. 2004. Invited review: Guidelines for measuring and reporting calf and heifer experimental data. J. Dairy Sci. 87:3577-3580.

Kim, Y. O., S. A. Yoon, Y. M. Ku, C. W. Yang, Y. S. Kim, S. Y. Kim, E. J. Choi, Y. S. Chang, and B. K. Bang. 2003. Serum albumin level correlates with disease severity in patients with hemorrhagic fever with renal syndrome. J. Korean Med. Sci. 18:696-700.

Klein, C. J., ed. 2002. Nutrient requirements for preterm infant formulas. J. Nutr. 132:1395S-1577S.

Lammers, B. P., A. J. Heinrichs, and A. Aydin. 1998. The effect of whey protein concentrate or dried skim milk in milk replacer on calf performance and blood metabolites. J. Dairy Sci. 81:19401945.

Liou, Y. A., D. J. King, D. Zibrik, and S. M. Innis. 2007. Decreasing linoleic acid with constant a-linolenic acid in dietary fats increases (n-3) eicosapentaenoic acid in plasma phospholipids in healthy men. J. Nutr. 137:945-952.

Merchant, A. T., G. C. Curhan, E. B. Rimm, W. C. Willett, and W. W. Fawzi. 2005. Intake of n-6 and n-3 fatty acids and fish and risk of community acquired pneumonia in US men. Am. J. Clin. Nutr. 82:668-674.

Merck Veterinary Manual. 2008. Hepatic Disease in Large Animals: Introduction. Accessed Sep. 16, 2010. http://www.merckvetmanual $\mathrm{com} / \mathrm{mvm} /$ index.jsp?cfile $=\mathrm{htm} / \mathrm{bc} / 22800 . \mathrm{htm}$

Nancey, S., J. Bienvenu, B. Coffin, F. O. Andre, L. Descos, and B. Flourie. 2002. Butyrate strongly inhibits in vitro stimulated release of cytokines in blood. Dig. Dis. Sci. 47:921-928.

NRC. 2001. Nutrient Requirements of Dairy Cattle. 7th rev. ed. Natl Acad. Sci., Washington, DC.

Orhue, N. E. J., E. A. C. Nwanze, and A. Okafor. 2005. Serum total protein, albumin and globulin levels in Trypanosoma brucei-infected rabbits: Effect of orally administered Scoparia dulcis. Afr. J. Biotechnol. 4:1152-1155.

Orr, C., D. P. Hutcheson, and G. B. Thompson. 1988. Nitrogen kinetics of infectious bovine rhinotracheitis-stress calves. J. Anim. Sci. 66:1982-1989.

Peng, L., Z. R. Li, R. S. Green, I. R. Holzman, and J. Lin. 2009. Butyrate enhances the intestinal barrier by facilitating tight junction assembly via activation of AMP-activated protein kinase in Caco-2 cell monolayers. J. Nutr. 139:1619-1625.

Robertson, J. B., and P. J. Van Soest. 1981. The Detergent System of Analysis and its Application to Human Foods. Cornell University, Ithaca, NY.

Saemann, M. D., G. A. Böhmig, C. H. Österreicher, H. Burtscher, O. Parolini, C. Diakos, J. Stöckl, W. H. Hörl, and G. J. Zlabinger. 2000. Anti-inflammatory effects of sodium butyrate on human monocytes: Potent inhibition of IL-12 and up-regulation of IL-10 production. FASEB J. 14:2380-2382. http://dx.doi.org/10.1096/ fj.00-0359fje.

Sander, E. G., R. G. Warner, H. N. Harrison, and J. K. Loosli. 1959 The stimulatory effect of sodium butyrate and sodium propionate on the development of rumen mucosa in the young calf. J. Dairy Sci. 42:1600-1605.

Smith, A. D. H., D. R. Crabtree, J. L. J. Bilzon, and N. P. Walsh 2010. The validity of wireless iButtons and thermistors for human skin temperature measurement. Physiol. Meas. 31:95-114. 
Terosky, T. L., A. J. Heinrichs, and L. L. Wilson. 1997. A comparison of milk proteins sources in diets of calves up to eight weeks of age. J. Dairy Sci. 80:2977-2983.

van den Borne, J. J. G. C., G. E. Lobley, M. W. A. Verstegen, J. Muijlaert, S. J. J. Alferink, and W. J. J. Gerrits. 2007. Body fat deposition does not originate from carbohydrates in milk-fed calves. J. Nutr. 137:2234-2241.

van Marken Lichtenbelt, W. D., H. A. M. Daanen, L. Wouters, R. Fronczek, R. J. E. M. Raymann, N. M. W. Severens, and E. J. W. Van Someren. 2006. Evaluation of wireless determination of skin temperature using iButtons. Physiol. Behav. 88:489-497.

Van Soest, P. J., J. B. Robertson, and B. A. Lewis. 1991. Methods for dietary fiber, neutral detergent fiber, and nonstarch polysaccharides in relation to animal nutrition. J. Dairy Sci. 74:3583-3597.
Wildman, E. E., G. M. Jones, P. E. Wagner, R. L. Bowman, H. F. Troutt Jr., and T. N. Lesch. 1982. A dairy cow body condition scoring system and its relationship to selected production characteristics. J. Dairy Sci. 65:495-501.

Zhao, G., T. D. Etherton, K. R. Martin, P. J. Gillies, S. G. West, and P. M. Kris-Etherton. 2007. Dietary $\alpha$-linolenic acid inhibits proinflammatory cytokine production by peripheral blood mononuclear cells in hypercholesterolemic subjects. Am. J. Clin. Nutr. 85:385-391. 